\title{
Financial Feasibility Study for New Investment in New Digital Product of PT Telkom Indonesia (Case Study: SKP Project)
}

\author{
Fadel Mohammad Islam, and Ahmad Danu Prasetyo
}

\begin{abstract}
SKP is an integrated stock management system application. With SKP, PT Telkom Indonesia provides solutions to business owners in the form of connectivity and services. Proper planning of business strategy is needed based on a proper feasibility study, so SKP project can generate economic benefits for PT Telkom Indonesia and all the stakeholders. SKP has not calculated the financial projections for it to proceed to the market and meet PT Telkom Indonesia regulation. A financial feasibility study would measure the revenue projection, and cost structure such as cash flow, balance sheet, and income statement projection. At the end of this model, there will be a conclusion of the feasibility of the project using internal rate of return (IRR), net present value (NPV), and payback period (PP) as parameters. If the project is feasible, there will be a sensitivity risk analysis to find out the most sensitive variable. According to feasibility test result, it is concluded that the SKP project can benefit PT Telkom Indonesia. This can be seen from the FCFF calculation which results in a positive NPV with a value of $R p$ 5.229.648.128, and IRR of $67,26 \%$ which is greater than the project WACC of $17,94 \%$. From the payback period requirements set by PT Telkom Indonesia, the project is estimated to have a PP of 2,02 years. The result of SKP's financial projections is also supported by Monte Carlo simulations which show the effect of changes to influential variables, with simulation results show a possible NPV>0 of $87,53 \%$.
\end{abstract}

Index Terms - Feasibility Study, Digital Product, Risk, Telkom, FCFF, WACC, NPV, IRR, PP.

\section{INTRODUCTION}

SKP product is an integrated stock management system application. With SKP product, PT Telkom Indonesia provides solutions to business owners in the form of connectivity and services. Proper planning of business strategy is needed based on a proper feasibility study, so the SKP project can generate economic benefits for PT Telkom Indonesia and all the stakeholders.

While SKP project is in the Business Model Validation (BMV) phase, it turns out that SKP has not calculated the financial projections for the project to proceed to Go To Market (GTM) phase, in order to meet the regulations set by PT Telkom Indonesia product innovation incubation management. PT Telkom Indonesia regulate incubation that startups must achieve certain achievements to 'graduate' from the program. After this project is completed, SKP products will be absorbed as part of the PT Telkom Indonesia business portfolio. Correspond to this issue, the author develop a

Published on October 7, 2020

Fadel Mohammad Islam, Bandung Institute of Technology, Indonesia

(e-mail: fadel.mohammad@sbm-itb.ac.id) feasibility study to propose a feasible strategy according to the results of additional research and analysis to strengthen the project's profitability.

The main objective of this research is to conduct an investment project analysis of whether the project is financially feasible or non-feasible. From the result of the feasibility study calculation, the first indicator in the project feasibility test is the net present value (NPV) of $\mathrm{Rp}$ 5.229.648.128. With those results, the NPV value of the project is more than 0 , it could be stated that this project exceeded the feasibility test primarily based totally on the NPV indicator.

From the calculation outcome, it could be feasible because the IRR value is $67,26 \%$, above the weighted average cost of capital of the project that equal to $17,94 \%$ it shows that doing the project can generate economic advantages to the organization due to the fact the project will produce an IRR more than the weighted average cost of capital. After calculating the FCFF, the payback duration is 2,02 years, this is still below the tolerance set by the PT TELKOM INDONESIA policy which stipulates the maximum payback duration is under five years. Based on those 3 indicators, the project is stated to be feasible to continue to the GTM stage

\section{LITERATURE REVIEW}

\section{A. Business Situation Analysis}

In order to develop a good analysis, there are many techniques can be use, in this research the analysis divided into 2 parts external and internal analysis, using Porter 5 Forces to analyze the market situation that the project will be included, and using competitor analysis to analyze product advantages towards direct competitor to compete in the current industry. Internal analysis is performed using VRIO based framework, by identifying project resources.

Based on an external analysis in the form of industrial environmental analysis, it can be concluded that the SKP project is in a very competitive industry or according to Porter's framework is an unattractive industry, this is indicated by the fact that there are many competitors engaged in the industry. In addition, there are substitute products for SKP products in form of conventional market-place, where people can sell directly on the market-place without the help of SKP products. Result from competitor analysis indicate there are 3 direct competitors in current industry which are Bigcommerce, Shoppify, and Sirclo. This makes potential

Ahmad Danu Prasetyo, Bandung Institute of Technology, Indonesia (e-mail: ahmad.danu@sbm-itb.ac.id) 
customer have as many choices as they want. The only advantage that SKP has is only cheapest subscription fee compare to other competitors, but with cost of incomplete features.

Internally, the resource that makes SKP different from the rest is the brand image of PT Telkom Indonesia, which makes it vulnerable to competition. There are so many features that must be added to make SKP products superior to other products.

Competitive advantage in the form of a brand image could be categorized as not strong enough to support competition in the industry. Lessons learned from the previous PT Telkom Indonesia market-place product BLANJA.com case that was unable to compete and eventually had to close, where BLANJA products had reputational resources from PT Telkom Indonesia. For this reason, SKP products must leave the comfort of PT Indonesia brand image, and create another competitive advantage which is the original competitive advantage of the product in order to success in GTM stage.

\section{B. Investment Decision Analysis}

Investment analysis is a broad term for varied methods of investment assessment, industrial sector, and economic trends. this could involve mapping past returns to predict future performance, selecting the kind of investment that most closely fits the requirements of investors. the aim of investment analysis is to see how likely investments are going to be created and how appropriate for certain investors. Key factors in investment analysis include the proper entry value, the expected time horizon for holding investments, and also the role of investments within the portfolio as a whole. the most commonly used ways for deciding investment choices are net present value (NPV), Internal rate of return (IRR), and Payback period (PP).

\section{METHODOLOGY}

The first stage is to analyze the condition according to the industry that the project will enter. Porter's Five Forces is a tool for understanding the competitiveness of the business environment, and identifying your strategy's potential profitability otherwise from this analysis will identify an opportunity and threats that Sakoo will face. Competitor analysis will show the strengths and weaknesses of each competitor so that it can be a reference to create a competitive advantage against competitors.

The second stage is to analyze the internal condition of SKP prime, this analysis used to identify the capability of the SKP project, and what limitation that PT Telkom Indonesia set as the owner of this project. The third stage is to conduct a financial feasibility study of the project. It is a model that measures the projection of revenue, and cost structure to this project, such as cash flow projection, balance sheet projection, income statement projection to the project. At the end of this model there will be conclusion of the feasibility of the project whether the project is feasible or not feasible, using net present value (NPV), internal rate of return (IRR), and payback period (PP) as investment decision parameters.

In addition to the investment of the project, if the project categorized as a non-feasible, it will be added a sensitivity and risk analysis for determining what variable influence project the most. This sensitivity and risk analysis will also be a recommendation to all stakeholders, to which variable are the most sensitive to maintain the project feasibility. The recommendation will be given by considering external conditions, internal conditions, and the feasibility study of this project.

\section{FINDINGS AND ARGUMENT}

\section{A. Revenue Projection}

In this study, revenue projections are based on the multiplication of the number of customers multiplied by the subscription price of 5 types of products, here are some assumptions used:

1. SKP customers in the first year are projected from $1 \%$ of PT Telkom Indonesia digital business customer segmentation as much 2000 customer.

2. The projected number of users in each type of package is obtained from historical SKP sales data when in the BMV stage.

3. SKP customer growth is a management target of $20 \%$ per year. to turn over ordinary customers into a premium targeted at $5 \%$ per year.

4. The SKP project recorded revenue in 2019 from the sales of experimental products at the BMV stage of 71 million rupiah

5. The SKP project will begin to enter the go to market stage in 2020 with product development starting in 2018 2019

6. There is no payable or receivable because the customer will get a subscription when paying, the payment method used is transferred via a virtual account

TABLE I: REVENUE PROJECTION (IN MILLION RUPIAH)

\begin{tabular}{cccccc}
\hline \hline Subscription & 2020 & 2021 & 2022 & 2023 & 2024 \\
\hline Micro & 5,98 & 12,82 & 17,22 & 22,67 & 29,75 \\
\hline Lite & 84,38 & 114,02 & 152,14 & 200,84 & 263,12 \\
\hline Business & 440,49 & 602,13 & 810,39 & 1078,0 & 1419 \\
\hline Pro & 281,21 & 384,98 & 518,76 & 691,15 & 912,33 \\
\hline Custom & 2184 & 2949 & 3980 & 5189 & 6795 \\
\hline $\begin{array}{c}\text { Total } \\
\text { Revenue }\end{array}$ & 2996 & 4063 & 5478 & 7181 & 9420 \\
\hline \hline
\end{tabular}

\section{B. Operating Expenditure}

In business activities in the SKP project, the costs incurred will be calculated in operational costs. These costs are divided into 3 components, those are general and administrative expenses, marketing expenses, and research and development expenses. Of the three components, there are several assumptions:

1. General and administrative expenses increase every year following the inflation rate with an average value of $3,37 \%$ per year.

2. An increase in marketing costs is projected at $10 \%$ per year.

3. An increase in research and development costs is projected to reach $20 \%$ per year.

TABLE II: OPERATING EXPENDITURE (IN MILLION RUPIAH) 


\begin{tabular}{ccccc}
\hline \hline Year & $\begin{array}{c}\text { Sales \& } \\
\text { Marketing } \\
\text { Expenses }\end{array}$ & $\begin{array}{c}\text { General \& } \\
\text { Administrative } \\
\text { Expenses }\end{array}$ & $\begin{array}{c}\text { R\&D } \\
\text { Expenses }\end{array}$ & $\begin{array}{c}\text { Total } \\
\text { Expense }\end{array}$ \\
\hline 2018 & - & - & - & - \\
\hline 2019 & - & - & - & - \\
\hline 2020 & 360,0 & 1502,7 & 10,8 & 1873,5 \\
\hline 2021 & 396,0 & 1553,3 & 13,0 & 1962,3 \\
\hline 2022 & 435,6 & 1605,6 & 15,6 & 2056,8 \\
\hline 2023 & 479,2 & 1659,7 & 18,7 & 2157,5 \\
\hline 2024 & 527,1 & 1715,5 & 22,4 & 2265,0 \\
\hline \hline
\end{tabular}

\section{Weighted Average Cost of Capital}

In determining Beta for calculations using the CAPM method, it is done using historical price data from PT. Telkom Indonesia as the parent company of the project. By regressing the price data from PT. Telkom Indonesia with the Indonesia Stock Exchange (IDX) index, as comparison beta of from PEFINDO and SAAS industry beta from Damodaran is used.

TABLE III: BETA USED

\begin{tabular}{cccc}
\hline \hline Source & Regression & PEFINDO & Damodaran \\
\hline Beta & 0,5 & 0,778 & 1,2 \\
\hline \hline
\end{tabular}

In line with the project using $100 \%$ internal funding, the WACC calculation only uses the cost of equity as the WACC value. For risk free market author using 10 years government bond (FR0082) with 7\% rate. The calculation also using average monthly market return $-0,11 \%$ and $-1.32 \%$ yearly

TABLE IV: WACC CALCULATION

\begin{tabular}{cccc}
\hline \hline Beta & Regression & PEFINDO & Damodaran \\
\hline Cost of Equity & $2,84 \%$ & $0,53 \%$ & $-2,98 \%$ \\
\hline \hline
\end{tabular}

From the above equation which refers to the CAPM method using 3 different betas, the cost of equity is 2,84\%, $0,527 \%,-2,894 \%$ which is smaller than the general cost of debt and the risk-free rate, it is caused by the average of market return in Indonesia is minus and the biggest impact is from the downfall of IDX in March 2020, so this calculation is considered unreasonable or considered as ineffective because cost of equity cannot be less than risk free, it not represent the main idea of the investor in general. For better result, the calculation of equity costs is adjusted using WACC calculation using ROE.

By using the average ROE for the Software industry (Systems and Applications) obtained from the Damodaran, the WACC value is $17,94 \%$, this calculation is a more effective calculation than the CAPM method, so the WACC calculation is used in the next calculation in this study.

\section{Feasibility Indicator}

From the FCFF calculations can be developed into a feasibility test. In addition, with the help of feasibility analysis can determine rational decisions whether an investment is feasible or not feasible.

Therefore, there are three methods for evaluating using Net Present Value (NPV), Payback Period, and Internal Return Rate (IRR). Net Present Value aims to identify net changes in cash flow associated with the purchase of fixed assets and discounts up to present value. To find out the total NPV we need to compare all the proposed projects with a positive NPV to make the project acceptable.

Payback Period is the determination period to generate sufficient cash flow from a project to pay the initial investment, with the help of the payback period, investors can calculate the project risk because it will focus on the payback period. Finally, the Internal Rate of Return, as an indicator of project investment efficiency.

TABLE V: FEASIBILITY INDICATOR

\begin{tabular}{ccc}
\hline \hline Indicator & Value & Threshold \\
\hline Net Present Value & Rp5.229.648.128,49 & $>0$ \\
\hline IRR & $67,26 \%$ & $16,9 \%$ (WACC) \\
\hline Payback Period & 2,02 years & $<5$ years \\
\hline \hline
\end{tabular}

Based on the results of calculations, the first indicator in the project feasibility test is the net present value (NPV) of Rp 5.229.648.128,49. With these results, the NPV value of the project is greater than 0 , it can be said that this project passed the feasibility test based on the NPV indicator.

The second indicator is the internal rate of return. from the calculation results, it can be seen the IRR value of $67,26 \%$, the value is greater than the weighted average cost of capital of the project that is equal to $17,94 \%$ it indicates that running the project can generate economic benefits to the company because the project will produce a profit greater than the weighted average cost of capital. According to the internal rate of return (IRR) indicator, this project can be said to be feasible.

Based on the calculation, the payback period is 2,02 years. This is still within the tolerance limits set by PT Telkom Indonesia start-up incubation rules which set a maximum limit for 5 years. Based on these indicators the project is categorized as feasible.

\section{E. Sensitivity Risk Analysis.}

Sensitivity analysis is the study of how the uncertainty in the output of a mathematical model or system (numerical or otherwise) can be divided and allocated to different sources of uncertainty in its inputs. Therefore, to find the risk measurement of the project may look at the Tornado Diagram to perceive important variables that affected the project feasibility. This diagram can directly show the dependent variables within the project.

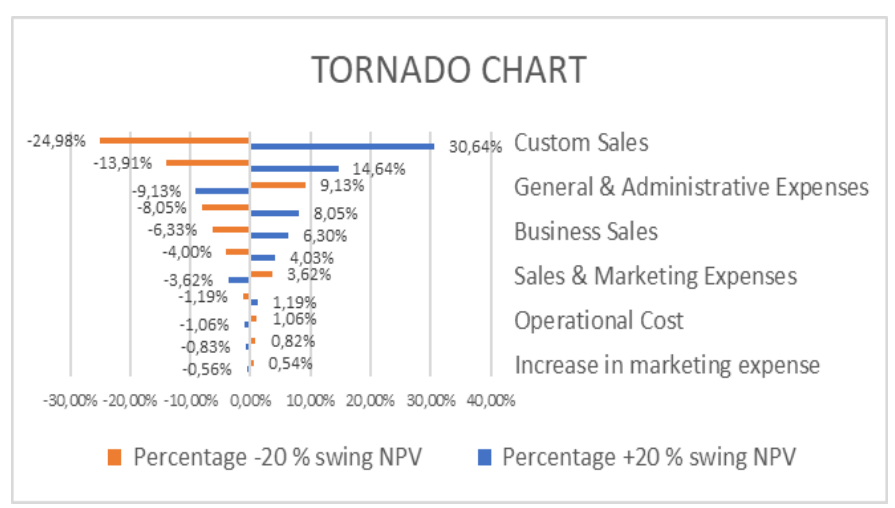

Fig. 1. Tornado Chart.

There are 4 most sensitive variables to the project, which are Custom subscription sales, Customer growth, G\&A Expenses, and Customer premium turnover/year. These 4 variables could be highlighted for the SKP management to maintain project profitability when going to market phase is running. 


\section{F. Scenario Analysis}

Scenario analysis is obtained after conducting a sensitivity analysis. after obtaining several variables that affect the project NPV from the previous analysis. After getting these variables, determine the best and worst possibilities that might change from all variables.

TABLE VI: SCENARIO SIMULATION

\begin{tabular}{cccc}
\hline \hline Variable & Worst Case & Base Case & Best Case \\
\hline Custom Sales & 292 & 364 & 437 \\
\hline Customer Growth & 0 & $20 \%$ & $40 \%$ \\
\hline $\begin{array}{c}\text { G\&A Expenses (In } \\
\text { Million Rupiah) }\end{array}$ & 1102 & 1002 & 1002 \\
\hline $\begin{array}{c}\text { Customer premium } \\
\text { turnover/year }\end{array}$ & $0,00 \%$ & $5,00 \%$ & $6,00 \%$ \\
\hline Business Sales & 630 & 788 & 946 \\
\hline $\begin{array}{c}\text { Pro Sales } \\
\text { Sales \& Marketing } \\
\text { Expenses (In } \\
\text { Million Rupiah) }\end{array}$ & 245 & 306 & 367 \\
\hline Lite Sales & 332 & 360 & 360 \\
\hline $\begin{array}{c}\text { Operational Cost (In } \\
\text { Million Rupiah) }\end{array}$ & $\mathrm{Rp} 101$ & $\mathrm{Rp} 84$ & $\mathrm{Rp} 84$ \\
\hline $\begin{array}{c}\text { Inflation Rate } \\
\text { Increase in } \\
\text { marketing expense }\end{array}$ & $4,37 \%$ & $3,37 \%$ & $2,48 \%$ \\
\hline $\begin{array}{c}\text { NPV (In Million } \\
\text { Rupiah) }\end{array}$ & $11,00 \%$ & $10,00 \%$ & $9,00 \%$ \\
\hline \hline
\end{tabular}

\section{G. Monte Carlo Simulation}

Monte Carlo simulation is a technique used to understand the impact of risk and uncertainty in financial, project management, cost, and other forecasting models. A Monte Carlo simulator helps one visualize most or all of the potential outcomes to have a better idea regarding the risk of a decision. The Monte Carlo simulation is to simulate a random variable between all variable considered in the scenario analysis for a random range between worst and best case that could happen in this project situation, for this case author only using 1000 times Monte Carlo simulation

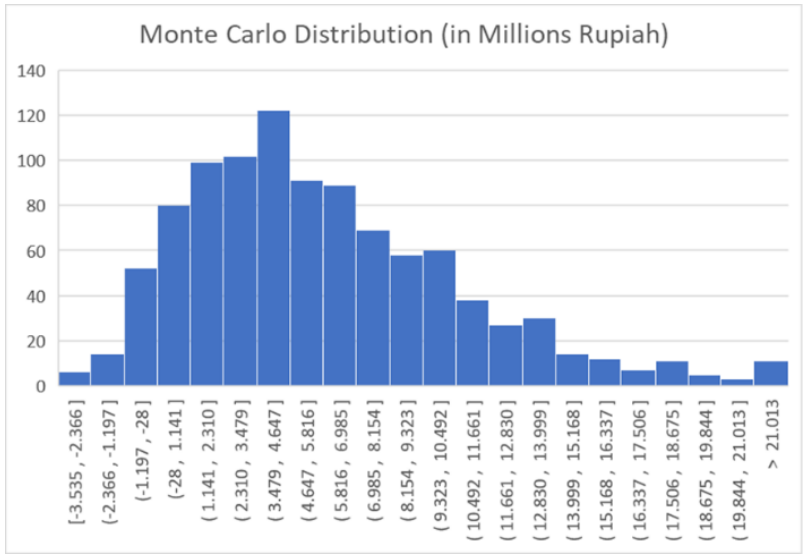

Fig. 2. Monte Carlo Distribution.

Monte Carlo simulation show minimum and maximum NPV projections, standard deviation, and the probability of NPV $<0$. It also shows probability of loss / NPV $<0$ is $12.47 \%$, that is this project has a bigger possibility of developing NPV $>0$ rather than NPV $<0$. Hence, the simulation's mean of NPV, the skewness, kurtosis, and the probability of generating negative NPVs of this sample proves that the simulation model is accurate. Based on that analysis it can be concluded that the project is most likely profitable and feasible to be running in to go to market phase.

\begin{tabular}{lc}
\multicolumn{2}{c}{ TABLE VII: Monte CARLO SIMULATION } \\
\hline \hline Min & Standar Deviation \\
\hline Max & $-3667,00$ \\
\hline Mean & 28864,00 \\
\hline Std. Dev & 5581,00 \\
\hline Median & 4846,00 \\
\hline Kurtosis & 4841,00 \\
\hline Skewness & 1,44 \\
\hline Prob NPV $<0$ & 1,01 \\
\hline \hline
\end{tabular}

\section{CONCLUSION AND RECOMMENDATION}

\section{A. Conclusion}

The SKP Prime project is an initiation of digital business products by PT Telkom Indonesia employees who will enter the stage (GTM). SKP is made to be a product that generates revenue for PT Telkom. This project is in the PT Telkom start-up incubation environment, Amoeba management. SKP has a digital product concept in the form of marketplace integration applications, for managing stock and online store creation services, and adhering to a paid subscription business model.

As a newcomer, SKP will enter an unattractive market where there are already several players in the industry. From the results of internal and external analysis, the conclusion is that this project is very vulnerable competition with competitors. The product competitive advantages are in form of PT Telkom brand image and it considered as not sustainable, refers to example with BLANJA.com that still fail in competing in the market with bringing Telkom brand image as its competitive advantage. In addition to the need to upgrade products in order to win the competition, good financial planning through due diligence is an indispensable thing in this project to achieve the target of the Amoeba incubation program.

Based on the results of the feasibility tests that have been carried out, it can be concluded that the SKP project can benefit PT Telkom, in this case, the EBIS division. This can be seen from the FCFF calculation results which project a positive NPV project with a value of Rp 5.236.282.620 with an IRR of $67,31 \%$ which is greater than the project WACC of $17,94 \%$. From the payback period requirements set in the Telkom start-up incubation program, the project is estimated to have a payback period of 2,02 years. The period is still within the requirements set by PT Telkom, which is 5 years. The results of the project's financial projections are also supported by Monte Carlo simulations which show the effect of changes to influential variables, with simulation results showing a possible NPV > 0 of $87,53 \%$ with an average NPV of Rp 5.753.967.966.

\section{B. Recommendation}

From the results of this study, there are a number of recommendations that can help and can be applied by management to carry out this project. The recommendations 
that will be given based on the results of calculations and analysis that have been carried out in this study, here are some recommendations for the management of SKP project.

1. Based on the results of calculations that have been done, this project is very feasible to run, so management is advised to continue this project to the go to market (GTM) stage.

2. Based on external and internal analysis, this product enters a highly competitive industrial environment, where there are already players who have already entered the industry. SKP management's capabilities need to be improved to create new competitive advantages so that products can win in the competition in the market. Enhancements in the form of features in the product must also continue to be added, it must be maximized by utilizing the development and marketing cost slots whose portions are quite large.

3. In entering the go to market (GTM) stage, there are several variables that must be considered, because they can affect the project NPV, some of these variables must be continuously monitored and controlled so that the possibility of this projected loss becomes smaller and even zero. These variables are custom type sales, customer growth, G\&A Expenses, and premium customer turnover.

4. Because the type of custom subscription greatly influences NPV, it is recommended to be the main focus of the SKP marketing program, allocate marketing funds to attract customers with this type.

5. Allocate costs for existing customer service, in order to capture as many ordinary customers as premium customers, because it is included in one of the variables which are quite sensitive.

6. Customer growth is also one thing that is very influential on the NPV of this project so that from the large marketing budget allocation is used as much as possible to create customer growth. Enlarge marketing channels outside the Telkom Group network.

\section{REFERENCES}

[1] Aswarth Damodaran (2020). Betas: Average Industry Betas 2020. [Online] Available: pages.stern.nyu.edu/ adamodar/New_Home_Page /datafile/Betas.html.

[2] Aswarth Damodaran (2020). Betas: Average Industry ROE 2020. [Online] Available: pages.stern.nyu.edu/ adamodar/New_Home_Page /datafile/roe.html.

[3] Barney, Jay, Wright, Mike, Ketchen, \& David. (2001). The ResourceBased View of the Firm. Journal of Management. 27. 10.1177/014920630102700601

[4] Bharadwaj, \& Anandhi. (2000). A Resource-Based Perspective on Information Technology Capability and Firm Performance: An Empirical Investigation. MIS Quarterly. 24. 169-196. $10.2307 / 3250983$.

[5] Edith, \& Penrose (1995). The Theory of the Growth of the Firm. Oxford University Press.

[6] Gitman, Lawrence J, Chad J., \& Zutter. (2012). Principles of Managerial Finance. $12^{\text {th }}$ Edition. Global Edition: Pearson Educational Limited.

[7] R. Duane I, Robert E. H., \& Michael A. Hitt. (2011). The Management of Strategy: Concepts and Cases. $9^{\text {th }}$ Edition. South-Western Cengage Learning.

[8] R. Duane I., Robert E. H., \& Michael A. Hitt. (2011). The Management of Strategy: Concepts and Cases. $9^{\text {th }}$ Edition. South-Western Cengage Learning.

[9] Vrontis, D. (2003), "McDonald's. The Impact of the External Environment on its International Marketing Operations.

[10] Wandebori H. (2019). Manajemen Strategi Dalam Perspektif Indonesia. Bandung: ITB Press.

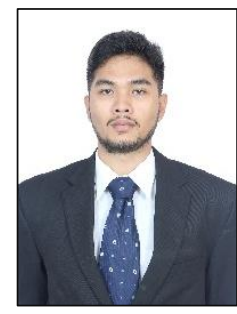

Fadel Mohammad Islam was born in Bandung, $28^{\text {th }}$ of October 1994. He earned bachelor degree in civil engineering from Parahyangan Catholic University Bandung. He is currently pursuing Master Degree in Business Administration from in Institut Teknologi Bandung and majoring in finance. He has work experience in construction as a quality control for Astra Honda Motor showroom development program between 2017-2018. Also as an intern in Telkom Digital Service Division at tribe e-commerce in 2020.

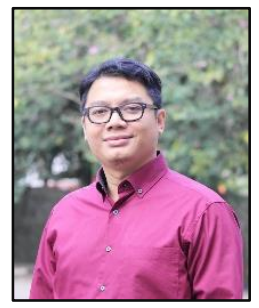

Ahmad Danu Prasetyo is a faculty member at the School of Business and Management, Bandung Institute of Technology (SBM ITB). He obtained a Ph. D degree from the Graduate School of Economics, Keio University, Japan. Danu earned his Bachelor in Industrial Engineering from Telkom Institute of Technology, Indonesia and Master of Science in Management from Bandung Institute of Technology, Indonesia. He got a cum laude

title for the later degree.

Danu received merit based scholarships for almost in every level of higher studies. Furthermore, he was appointed as Adjunct Researcher during his doctoral study at Keio University. He also had the opportunity to join Asian Development Bank Institute in Tokyo as Research Associate. Danu had also served the Ministry of Finance, Republic of Indonesia as a consultant for various projects, especially in Government Bond Market development.

Danu has a wide range of research interest in Economics and Finance, especially in Macroeconomic Policy, Fiscal Policy, Monetary Policy, Public Policy, Stock and Bond Market, and Personal Finance. Some of his papers were published in Scopus indexed journals such as International Journal of Economic Policy in Emerging Economies, Journal of Comparative Asian Development and Global Business and Economic Review. 